\title{
Irrelevant! Møte mellom to kulturer
}

\author{
Per Thorvaldsen og Ingvar Henne \\ Fakultet for ingeniør- og naturvitskap, Høgskulen på Vestlandet, Norge
}

\begin{abstract}
SAMMENDRAG: I denne artikkelen presenteres erfaringer og funn fra fire år med undervisning i emnet «Innføring i ingeniørfaglig yrkesutøvelse og arbeidsmetoder» ved Hogskulen på Vestlandet. Disse sees i sammenheng med det økende kravet om ex. phil. i all høyere utdanning. Våre ingeniørstudenter viste meget liten interesse for emnet ved oppstart i 2012, men ved å endre på pedagogikk og faglig tilnærming har studentene gradvis blitt mer interessert i dette dannelsesfaget. Skal en lykkes med å innføre ex. phil. i all høyere utdanning må man ta høyde for at de ulike studentgrupper har ulike preferanser og interesser.
\end{abstract}

Nøkkelord: Ex. phil., dannelse, innføringsemne, teknikk og samfunn, pedagogikk

\section{INNLEDNING OG BAKGRUNN}

Det er snart 60 år siden C.P. Snow holdt sin berømte Rede-forelesning om de to kulturer (Snow, 2008). I den forelesningen fortvilte han over avstanden mellom teknologene og humanistene. Han påpekte blant annet at termodynamikkens andre lov var vel så viktig for et opplyst menneske som Shakespeares verker. Han ønsket at det ble bygget bro mellom de to kulturer ved hjelp av kunnskapsutveksling.

I Norden har vi hatt en lang tradisjon i universitetsstudiene siden 1675 med den såkalte forberedende prøve - examen philosophicum (ex. phil.) - ment som et «dannelsesfag» som skal forberede studenter til videre studier. Innholdet $\mathrm{i}$ faget har variert gjennom tidene, og er $\mathrm{i}$ dag konsentrert om vitenskapshistorie, vitenskapsteori, vitenskapelig metode og etikk (Rørvik, 1999).

I den tradisjonelle ingeniørutdanningen har det ikke tidligere vært et «dannelsesfag» alá ex. phil. Kunnskapsdepartementet ga i 2006 NOKUT oppdraget å evaluere ingeniørutdanningen. NOKUT avga sin rapport «Evaluering av ingeniørutdanningen» i 2008 (NOKUT, 2008). I den ble det fremhevet at ingeniørutdanningen måtte sees i lys av Bolognaprosessen, og at den måtte akademiseres. Den norske ingeniørutdanningen er i henhold til den europeiske akkreditering gitt av FEANI (European Federation of National Engineering Associations, 2017). At akademisering kunne bli en utfordring er blant annet blitt belyst av Guenter Heitmann (Heitmann, 2005, s. 452) og NOKUT. «Mangelen på forskertilknytning $\mathrm{i}$ ingeniørutdanningen medfører at studentene ikke får god nok opplæring i kritisk tenkning, analyse og bruk av vitenskapelige metoder med kildekritikk» (NOKUT, 2008, s. 15). Sammenslåingen av universiteter og høgskoler til større enheter er også en pådriver for kravet om at all høyere utdanning skal ha et ex. phil. lignende emne.

I 2011 fastsatte Kunnskapsdepartementet så en ny forskrift om rammeplan for ingeniørutdanningen (Lovdata, 2011). I den var det et nytt og spennende dannelsesemne «Innføring i ingeniørfaglig yrkesutøvelse og arbeidsmetoder» som representerte noe helt nytt $\mathrm{i}$ ingeniørutdanningen - et slags «ex. phil. light». I de tilhørende nasjonale retningslinjer (Universitets- og høgskolerådet, 2011) som skulle sikre kvaliteten, var det angitt førende beskrivelser av læringsutbytte. I 2016 har Arbeiderpartiet i sitt «Forslag til strategi for høyere utdanning og forskning» (Arbeiderpartiet, 2016, s. 20) framsnakket behovet ex. phil. også for ingeniører, og prorektor Nina Waaler ved HiOA mener at ex. phil. må til «for at studentene skal kunne løse de samfunnsutfordringer en ennå ikke kjenner med teknologi som ennå ikke er funnet opp» (Waaler, 2016).

Da burde vel alt ligge til rette for å oppfylle C.P. Snows drøm om å forene teknologer og humanister? Det faktum at Dannelsesutvalget for høyere utdanning ikke hadde en eneste teknolog som medlem (Dannelsesutvalget for høyere utdanning, 2009), ingeniørstudentenes uttrykte motvilje mot ex. phil. (Svendsen, 2016), og egne erfaringer med undervisning i «Innføring i ingeniørfaglig yrkesutøvelse og arbeidsmetoder» kan tyde på at det enda er et stykke å gå før en er i mål med ingeniørdannelsen.

I et nordisk perspektiv så finnes det tilsvarende ingeniørdannelsesemner i Sverige og Danmark. Der blir tema som bærekraft, ingeniøretikk og menneske, samfunn og teknikk tatt opp (Lönngren, 2014). 
Vår artikkel viser hvordan studenter har tatt i mot det nye dannelsesemnet. Etter å ha undervist emnet noen år ønsket forfatterne å få bedre kunnskap om studentenes forventninger, meninger, motivasjon og interesse for emnet. Dette er målinger som forfatterne ikke kan se har blitt presentert tidligere og gir dermed ny viten om studenters holdning til emnet. At det finnes liten eller ingen forskning på området understøttes av Alpay et al. (Alpay, Ahearn, Graham, \& Bull, 2008).

"Many of the abovementioned initiatives have an implicit assumption that the students themselves will be better motivated towards their studies, and indeed an engineering career, if they are able to effectively engage with the big issues, and of course, appreciate their potential impact on these issues as future engineers. A lthough some anecdotal evidence exists to support such an assumption, to date little research exists on evaluating the motivations, life aspirations and course expectations of engineering students.»

Artikkelen gir også et innblikk i hvordan ulike undervisningsformer påvirker interessen for emnet og studentenes motivasjon for læring.

Målingene er gjort ved hjelp av surveyer og underveisevalueringer i «Innføring i ingeniørfaglig yrkesutøvelse og arbeidsmetoder». I tillegg er de samme målingene utført på siste års studenter for å se om studentene endret syn på emnet over tid. Målingene var 'multiple choice' spørreundersøkelser hvor studentene kunne gi utfyllende svar på noen punkter.

\section{BEGREPSAVKLARING - DANNELSESASPEKTET INNENFOR INGENIØRFAG}

Hva er ingeniørdannelse, og skiller den seg fra dannelse og allmenndannelse? I følge Store Norske Leksikon er dannelse eller danning formingen av menneskets personlighet, oppførsel og moralske holdning gjennom oppdragelse, miljø og utdanning, mens begrepet allmenndannelse brukes om et minstemål av dannelse som blir sett på som noe som burde være felles for alle innbyggerne $\mathrm{i}$ et samfunn (Store norske leksikon, 2017).

Det som C.P. Snow (Snow, 2008) pekte på, og Dietrich Schwanitz (Schwanitz, 2005) følger opp, er at hverken naturvitere eller ingeniører er blitt opptatt i det gode dannelsesselskap. «Vi behøver riktignok ikke å skjule naturvitenskapelige kunnskaper, men de hører ikke med til dannelsen» (Schwanitz, 2005). Dannelse er nærmest å betrakte som en fritidssyssel for overklassen som nytteorienterte ingeniører ikke trenger å kaste bort tiden sin på.

Det er ikke like lett å finne en definisjon av ingeniørdannelse, men det generelle læringsutbyttet for ingeniørutdanningen gitt i Forskrift om rammeplan for ingeniørutdanningen (Lovdata, 2011) er et godt utgangspunkt:

«Kandidaten har innsikt i miljømessige, helsemessige, samfunnsmessige og økonomiske konsekvenser av produkter og løsninger innenfor sitt fagområde og kan sette disse i et etisk perspektiv og et livsløpsperspektiv. Kandidaten kan formidle ingeniørfaglig kunnskap til ulike målgrupper både skriftlig og muntlig på norsk og engelsk og kan bidra til å synliggjøre teknologiens betydning og konsekvenser».

\section{UTVIKLING AV EMNET «INNFØRING I INGENIØRFAGLIG YRKESUTØVELSE OG ARBEIDSMETODER»}

Ved institutt for elektrofag ved Høgskulen på Vestlandet (HVL) tok vi rammeplanen for ingeniørutdanningens intensjoner om ingeniørdannelse på alvor, og laget et innhold $\mathrm{i}$ tråd med de generelle læringsutbyttebeskrivelsene gitt i malen for utarbeidelse av emnene.

I de nasjonale retningslinjer (Universitets- og høgskolerådet, 2011) ble det gitt forslag til innhold i emnet «Innføring i ingeniørfaglig yrkesutøvelse og arbeidsmetoder» samt en læringsutbyttebeskrivelse. Forslaget til innhold var meget omfattende med stor grad av frihet til utforming. Ved å se på andre ingeniørutdanninger enn vår egen, kan det se ut som noen kanskje har tatt seg vel store friheter (Schive, 2015). Ved vårt institutt gjorde vi et nennsomt utvalg som speilet Kunnskapsdepartementets intensjoner med fokus på de mest relevante emnene. I emnet la vi inn profesjonsforståelse og ingeniørrolle, presentasjonsteknikk, prosjekt, design, elektrohistorie, etikk, vitenskapsteori, «søk \& skriv» (Søk \& skriv, 2017), bedriftsbesøk, og kronikkskriving i den teoretiske delen, og i tillegg et praktisk prosjektarbeid. Vår variant av «Innføring i ingeniørfaglig yrkesutøvelse og arbeidsmetoder» fikk emnekoden ING104. Det ble laget en forelesningsplan som avspeilte de ulike temaene som emnet inneholdt, og som relativt raskt satte studentene i gang med studentaktiv læring. 
Tabell 1 Forelesningsplan for høsten 2016 for ING104

\begin{tabular}{|c|l|l|}
\hline Uke & Forelesninger & Forprøver \\
\hline 33 & Start Ingeniørrollen (1t), Rapport (1t) & Kronikk gis \\
\hline 34 & Presentasjonsteknikk (2t), Rapport (1t) & Presentasjon gis \\
\hline 35 & Sitering - klassevis (2t), Rapport - felles (1t) & \\
\hline 36 & HMS (1t), Smarte sensorer, loT, Industri 4.0 (2t) & Kronikk inn \\
\hline 37 & Presentasjoner klassevis & Presentasjon vises \\
\hline 38 & ABB dag & \\
\hline 39 & Prosjekt (2t), Design (1t) & \\
\hline 40 & Elhistorie (1t), Prosjekt (2t) & \\
\hline 41 & Elhistorie (2t), Forskning (1t) & \\
\hline 42 & Labview introduksjon (3t) & \\
\hline 43 & Elhistorie (1t), Vitenskapshistorie (2t) & \\
\hline 44 & Elhistorie (1t), Vitenskapshistorie (2t) & Siste innlevering av prosjekt \\
\hline 45 & Elhistorie (1t), Etikk (2t) & \\
\hline 46 & Elhistorie (1t), Prosjekt fra industrien (2t) ABB & \\
\hline 47 & Oppsummering & \\
\hline
\end{tabular}

Forfatterne, som har lang fartstid i næringslivet før de ble en del av akademia, har observert at i utdanningssektoren virker det som de fleste innspill til endringer i studier kommer fra oven. Disse endringene blir motvillig adaptert i utdanningssektoren. Det tok derfor lang tid fra rammeplanen for ingeniørutdanningen ble fastsatt til vi kunne begynne med fagutvikling av emnet «Innføring i ingeniørfaglig yrkesutøvelse og arbeidsmetoder». Siden emnet var nytt og inneholdt mange elementer var det ikke lett å finne noen passende lærebok. Riktignok er det mange gode læremidler innen prosjektarbeid (Andersen \& Schwencke, 2012), men litteratur som omhandler elektrohistorie glimrer med sitt fravær. Først nå fem år etter, har Ronny Kjelsberg (Kjelsberg, 2017) fått utgitt en bok som dekker emnet rimelig godt.

Da emnet inneholdt mange elementer, var det naturlig å trekke inn en rekke ressurser til undervisningen. Det var eksterne forelesere fra akademia og næringsliv, samt en rekke egne aktører med spisskompetanse på de enkelte områder. Forelesninger ble valgt som metode i den teoretiske delen av emnet på grunn av antallet studenter som er omtrent 200 .

Vi hadde en forutanelse om at den teoretiske delen av dette emnet kanskje ikke ville bli det mest populære blant unge kommende ingeniører og det heller ikke var lett å finne lærerkrefter. Derfor valgte vi å bruke instituttleder i deler av undervisningen for å synliggjøre ham for studentene og dermed indirekte sende et signal om emnets betydning.

\section{ERFARINGER UNDERVEIS}

Tilbakemeldingene første året var todelte. Den praktiske delen med innføring i prosjekt og eget prosjektarbeid ble meget godt mottatt. Prosjektarbeidene har vært av typen trappepiano (Hjelle, 2012), ølbrygging (Myklebust, 2013), og elektriske terninger - hvor det har vært inkludert elektrofaglige elementer. Her meldte studentene tilbake at læring, relevans og nytteverdi var stor, og det viste seg også i eksamensresultatene. I tillegg var det morsomt og sosialt. Også bedriftsbesøk hos ABB ble godt mottatt.

I den teoretiske delen var studentenes respons katastrofal - av typen gitt i overskriften. De så ingen umiddelbar nytteverdi i å få kunnskap om elektrohistorie, selv om den ble relatert til oppbygging og virkemåte av moderne utstyr. Kravet om kronikkskriving ble møtt med vantro av typen «Jeg har ikke begynt på ingeniørstudiet for å skrive stil!», men tross dette fikk én av studentene sin kronikk på trykk i Bergens Tidende (Grøttvik, 2012). Også vitenskapsteori og etikk vekket liten interesse, selv om de beste forelesere og fagpersoner innen områdene var hyret inn (bl.a. Ragnar Fjelland, professor emeritus i vitenskapsteori ved UiB og Tom Skauge, førsteamanuensis i profesjonsetikk ved HVL). Det ble heller klaget på at en måtte forholde seg til så mange ulike forelesere.

Instituttleders beskrivelse av egen erfaring som ingeniør og ingeniørrollen generelt ble oppfattet som paternalsk og gammelmodig. "Han er full av seg selv», som en student så viselig ga uttrykk for i 
underveisevalueringen. Riktignok kom det også trøstende ord som at de følte med oss lærere som måtte undervise i dette tøyseemnet som var pålagt av myndighetene. Et forsøk på å øke interessen ved å bruke pop-kulturelle referanser som filmen «Blade Runner» (Scott, 1982), viste med all ønsket tydelighet generasjonsskillet. Vårt ønske var å vise en filosofisk film, men vi ble møtt med tilbakemeldinger som «Kulens inntrengning i kroppen følger ikke Newtons lover». Heller ikke smakebiter fra instituttets forskning (Thorvaldsen \& Henne, 2014) ble mottatt med synderlig interesse. Før presentasjonen startet, kom det klassiske spørsmålet «Er dette pensum?».

Basert på første års erfaringer har emnet blitt bedre strukturert. Den praktiske delen som studentene liker godt, er beholdt uforandret, mens den teoretiske delen har blitt bedre tilpasset publikum. Det er innført tvillingforelesninger - «Knoll og Tott» - basert på arven etter Øgrim og Ormestad (Ormestad \& Øgrim) og framsnakk av Arild Raaheim (Raaheim, 2013). Tilbakemeldingene på tvillingforelesningene er gode. Formen er infotainment som gjør det mulig med diskusjoner og meningsbrytninger i en forelesning for 200 studenter. Det at lærerne diskuterer og er uenige river studentene med, og reduserer terskelen for å stille spørsmål og delta aktivt i diskusjonen.

Videre har vi tatt i bruk responssystemer alá Kahoot (Kahoot, 2017) for å øke engasjement, studentaktivitet, og for å utføre surveyer. Som følge av studentenes sluttvurderinger av emnet, har en fokusert mer på studentaktive læringsformer som gruppearbeid, relevante praktiske oppgaver, og egne presentasjoner. Disse tiltakene har gjort studentene vesentlig mer positive til dannelsesemnet «Innføring i ingeniørfaglig yrkesutøvelse og arbeidsmetoder».

\section{METODE}

\subsection{Forskningsdesign}

Basert på erfaringene med «Innføring i ingeniørfaglig yrkesutøvelse og arbeidsmetoder», ble det ønskelig å måle studentenes endring i holdninger og interesse for emnet over tid. Ved bruk av responssystemet Kahoots surveyfunksjon ble holdninger og interesse for emnet målt for både første års studenter som hadde emnet og siste års studenter som hadde hatt emnet to år tidligere. Det ble utarbeidet åtte spørsmål til surveyen for å få avdekket studentenes meninger om emnet, og om det kunne finnes svarkorrelasjoner mellom enkeltspørsmål som kunne avdekke sammenhenger mellom for eksempel interesser og holdninger. Spørsmålene (se tabell 2) ble basert på erfaringer med underveisevalueringer som hadde gitt en indikasjon på hvor utfordringene med emnet lå.

\section{Tabell 2 Kahoot survey med 'multiple choice' spørsmål.}

\begin{tabular}{|c|c|c|}
\hline \# & Spørsmål & Svaralternativ \\
\hline 1 & Hva var mest relevant i ING104? & $\begin{array}{l}\text { «Elektrohistorie og ingeniørrollen», «Prosjekt», «Sitering» } \\
\text { og «Vitenskapshistorie» }\end{array}$ \\
\hline 2 & Hva ville du hatt mer av? & $\begin{array}{l}\text { «Elektrohistorie og ingeniørrollen», «Prosjekt», «Sitering» } \\
\text { og «Vitenskapshistorie» }\end{array}$ \\
\hline 3 & Hva synes du om kronikkoppgaven? & «Dårlig», «Tja», «Nyttig» og «God \\
\hline 4 & Hva synes du om presentasjonsoppgaven? & «Dårlig», «Tja», «Nyttig» og «God \\
\hline 5 & $\begin{array}{l}\text { Generell oppfatning: Litt unødig emne, } \\
\text { men det må vel til }\end{array}$ & «Enig» og «Uenig» \\
\hline 6 & Struktur: Emnet manglet en rød tråd & «Enig» og «Uenig» \\
\hline 7 & $\begin{array}{l}\text { Hadde dette emnet egnet seg bedre } \\
\text { senere i studiet? }\end{array}$ & «Ja», «Tja» og «Nei» \\
\hline 8 & $\begin{array}{l}\text { Hvordan var ditt helhetsinntrykk av } \\
\text { emnet? }\end{array}$ & $\begin{array}{l}\text { «Nyttig og interessant», «Nyttig og variert», «Greit nok» } \\
\text { og «Kjedelig og irrelevant» }\end{array}$ \\
\hline
\end{tabular}

For å gjøre en kvalitativt studie om hvordan nye undervisningsmetoder eventuelt hadde endret studentenes syn på emnet, ble underveisevalueringer fra henholdsvis 2012 og 2016 sammenlignet. Underveisevalueringene var anonyme og der kunne studentene gi sin usminkede mening om emnet.

Da den praktiske delen er meget godt likt av studentene, valgte en å fokusere på å finne ut hvorfor den teoretiske delen møter så store utfordringer. For å finne ut av det har det i tillegg til surveyer og 
underveisevalueringer vært dialoger med studenter og benyttet sluttevalueringer. I tillegg har obligatoriske øvelser og eksamen gitt oss en pekepinn om hvor skoen trykker. Både survey, underveisevalueringer, dialog med studenter og sluttevalueringer hadde til hensikt å utvikle emnet og undervisningsmetoder.

\subsection{Deltakere}

Institutt for elektrofag ved Høgskulen på Vestlandet har felles undervisning for alle studenter i den teoretiske delen av «Innføring i ingeniørfaglig yrkesutøvelse og arbeidsmetoder». I siste forelesning høsten 2016 gjennomførte man en survey med de førsteårsstudentene som holdt ut til siste forelesning (42 av totalt 200). Tilsvarende survey ble gjort med 61 avgangsstudenter i januar 2017. Disse avgangsstudentene hadde emnet høsten 2014.

Deltakere i underveisevalueringene var studenter i emnet høsten 2012 og 2016.

For å få vite litt mer om bakgrunnen til våre studenter, hadde vi en liten survey blant 109 førsteårstudenter. Det var spesielt to spørsmål som har relevans i denne sammenheng, nemlig arv og alternative studievalg. 30\% hadde en far som var ingeniør, $4 \%$ en mor som var ingeniør og $8 \%$ hadde foreldre som begge var ingeniører. Det kan se ut som at ingeniøryrket er noe som går i arv. Det andre spørsmålet var om alternativt studium dersom en ikke valgte ingeniørstudiet. $51 \%$ ville ha valgt realfag, $31 \%$ økonomi/juss, mens kun $9 \%$ ville valgte enten humaniora eller samfunnsfag. Ingeniørstudentene hadde altså helt klare preferanser innen fag som kunne relateres til ingeniørfag.
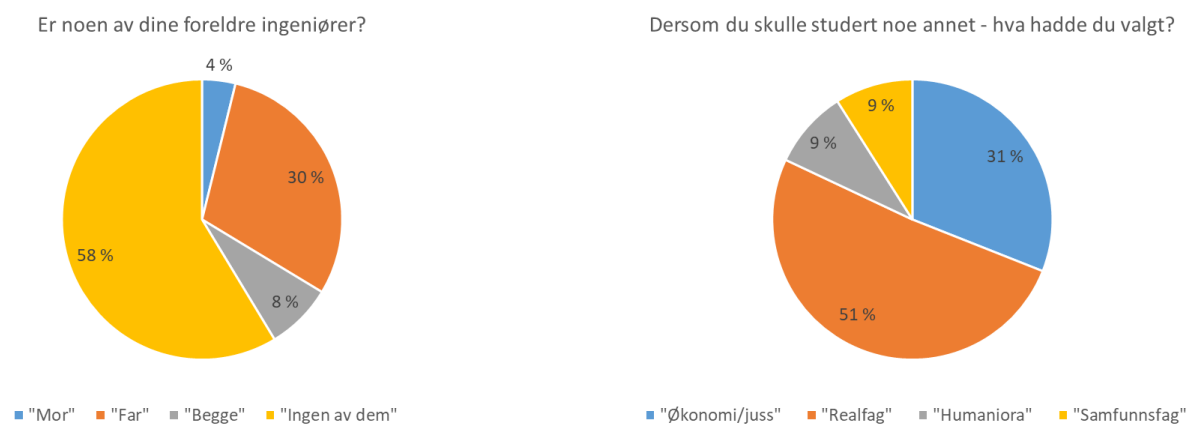

Fig. 1. Arv og alternative studier blant førsteårsstudenter

\section{MÅLINGER - PRESENTASJON AV FUNN}

\subsection{Survey}

\subsubsection{Relevans}

Studentene ble spurt hva de syntes var mest relevant og hva de ville hatt mer av i kurset.

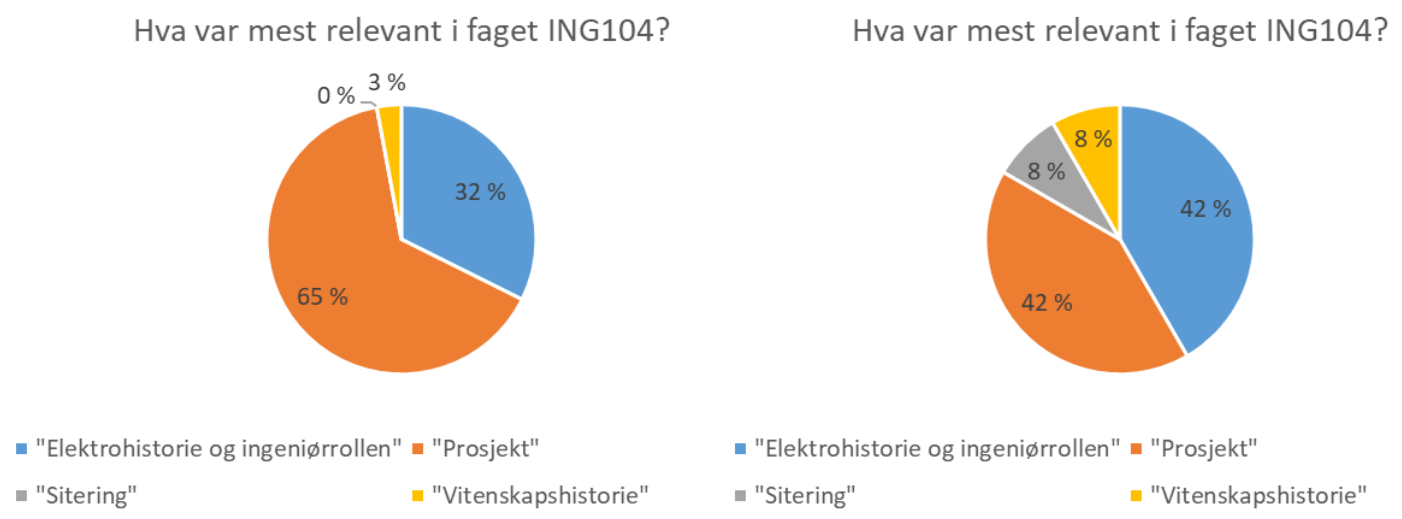

Fig. 2. Mest relevante emner. a) førsteårsstudenter b) avgangsstudenter 
Figur 2 viser klart at både førsteårsstudenter og avgangsstudenter syntes «Prosjekt» var mest relevant. Avgangsstudentene syntes ikke «Prosjekt» var like viktig som førsteårsstudentene, og det kan skyldes det faktum at avgangsstudenter blir utsatt for mer prosjektrelatert arbeid i sin bacheloroppgave. Det er interessant å observere at andelen som fant «Elektrohistorie og ingeniørrollen» relevant er høyere for avgangsstudentene. Dette kan handle om modning og det enkle faktum at de har blitt utsatt for en rekke emner hvor de er blitt undervist i elektrofag, og dermed sett den historiske konteksten til elektrofagene. «Sitering» syntes ingen førsteårsstudenter var relevant. Den enkle årsak til det kan være at de ikke har noe forhold til forskning eller forskningsbasert undervisning. Avgangsstudentene så litt mer relevans av «Sitering», men heller ikke de som skulle bruke det i sine bacheloroppgaver var synlig opptatt av temaet. «Vitenskapshistorie» syntes ikke førsteårsstudentene hadde noen relevans. Sisteårsstudentene syntes «Vitenskapshistorie» var noe mer relevant enn førsteårsstudentene, men for begge studentgrupper var interessen liten. Det kan virke som om studentgruppene tenker som byggingeniøren Ove Arup med Sidney-operaen på samvittigheten (Arup, 2017).

«Engineering is not a science. Science studies particular events to find general laws. Engineering design makes use of these laws to solve particular problems. In this it is more closely to art or craft.»

Dersom dette er tilfelle, forklarer det også hvorfor den praktiske delen av «Innføring i ingeniørfaglig yrkesutøvelse og arbeidsmetoder» er mest populær.

\subsubsection{Onsket fordeling}

Det neste spørsmålet omhandlet ønsket fordeling av innholdet i den teoretiske delen av emnet.

Hva ville du hatt mer av?

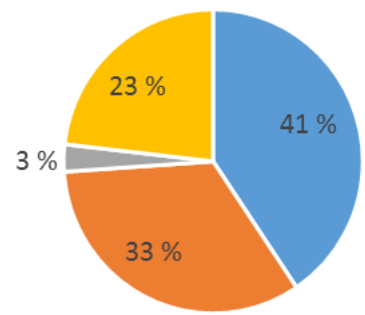

Hva ville du hatt mer av?

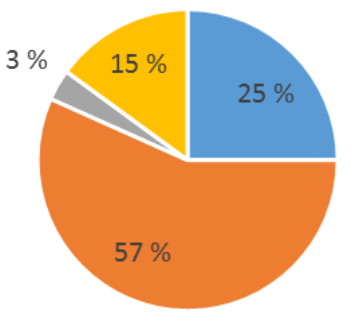

$$
\begin{aligned}
& \text { - "Elektrohistorie og ingeniørrollen" - "Prosjekt" } \\
& \text { - "Sitering" } \\
& \text { - "Vitenskapshistorie" }
\end{aligned}
$$

Fig. 3. Studentenes prioritering av emner. a) førsteårsstudenter b) avgangsstudenter

Da vi spurte om hvilke emner de ville hatt mer av, så vi et paradoks. Førsteårsstudentene ønsket mer «Elektrohistorie og ingeniørrollen» til tross for at dette ikke var det mest relevante. De ønsket også mer av «Vitenskapshistorie» som fikk svært lav score på relevans. Det kan synes som førsteårsstudentene syntes det var tilstrekkelig «Prosjekt» selv om dette hadde høyest relevans.

For avgangsstudentene er det imidlertid fortsatt klart størst ønske om mye «Prosjekt». Dette kan skyldes at avgangsstudentene akkurat startet med sin bacheloroppgave (som i høyeste grad er prosjektrelatert) da undersøkelsen ble gjennomført. En ser også at avgangsstudentene ville ha mindre av «Elektrohistorie og ingeniørrollen» enn førsteårsstudentene, og det kan tolkes som at de syntes det de fikk var tilstrekkelig.

«Sitering» var lite ønsket av både førsteårsstudenter og avgangsstudenter. 


\subsubsection{Kronikk}

Kronikkoppgaven ble av de emneansvarlige ansett som viktig for å lære studentene å uttrykke seg skriftlig og delta i samfunndebatten, og det var naturlig å spørre studentene hva de mente om oppgaven.

Hva synes du om kronikkoppgaven?

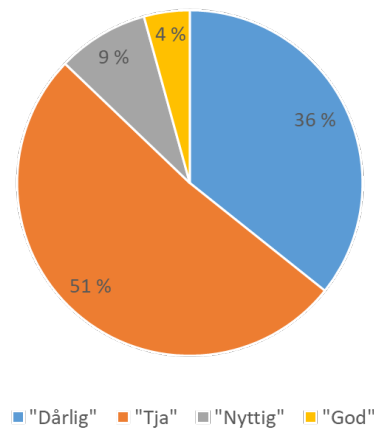

Hva syntes du om kronikkoppgaven?

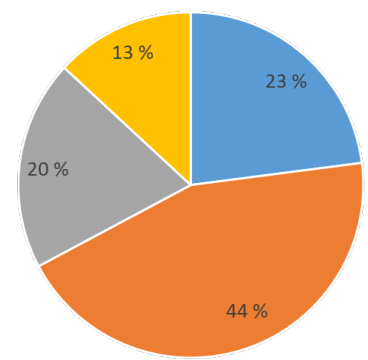

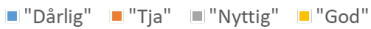

Fig. 4. Studentenes vurdering av kronikkoppgave. a) førsteårsstudenter b) avgangsstudenter

Her var tilbakemeldingen fra førsteårsstudenter og avgangsstudenter temmelig unison. De syntes enten oppgaven var «Dårlig» eller «Tja». Blant førsteårsstudentene var det kun få som syntes oppgaven var «God» eller «Nyttig». Det var vesentlig flere avgangsstudenter som syntes oppgaven var «God» eller «Nyttig».

Kronikkoppgavene som har blitt gitt har vært temmelig åpne, og et flertall av studentene har valgt 'planken' «Hvorfor ønsker jeg å bli ingeniør», men en god del studenter, særlig kvinner, har også valgt tema med innslag av etikk, bærekraft og miljø. Mange av de kvinnelige studentene skrev også om det å være kvinnelig ingeniør. Kjønn som tema var helt fraværende blant de mannlige studentene. 'Planken' har gitt oss lærere en god innsikt i hva som driver våre studenter. Det kan kort sammenfattes til sikkert arbeid, høy lønn, ønsket om å lage noe, og familie med ingeniørbakgrunn.

\subsubsection{Presentasjonsoppgaven}

I presentasjonsoppgaven skulle studentene presentere for de andre studentene noe de var interessert $\mathrm{i}$, eller lage en firmapresentasjon. De ble bedømt både for selve presentasjonen og for fremføringen. Da ingeniører i mange mulige henseender må presentere sitt arbeid for andre, mente emneutviklerne at dette kunne være en god oppgave som også hadde et studentaktiv element i seg.

Hva synes du om presentasjonsoppgaven?

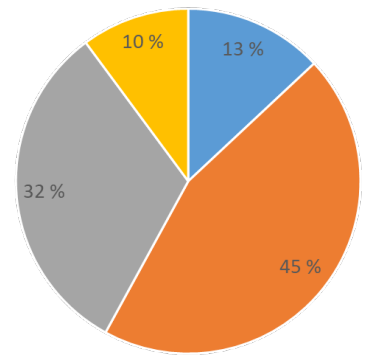

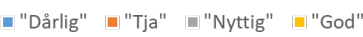

Hva syntes du om presentasjonsoppgaven?

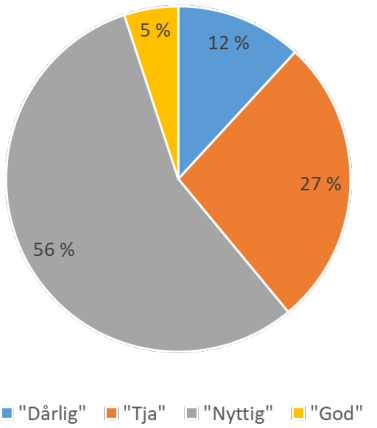

Fig. 5. Studentenes vurdering av presentasjonsoppgave. a) førsteårsstudenter b) avgangsstudenter

Blant førsteårsstudentene syntes brorparten at oppgaven var «Dårlig» eller «Tja». Dette står i klar kontrast til sisteårsstudentenes oppfatning som syntes oppgaven var «Nyttig» eller «God». En rimelig forklaring på dette kan være at sisteårsstudenter gjennom sitt studium har vært utsatt for en rekke presentasjoner og dermed sett nytten av det de lærte. Fra førsteårsstudenter kommer det påstander om at dette kan de fra grunn- og videregående skole. For lærerne som har sett studentenes presentasjoner, kan det fortone seg annerledes. Det er ofte et godt stykke igjen til profesjonelle presentasjoner. 


\subsubsection{Generell oppfatning}

For å finne ut litt mer om studentenes forhold til emnet, ble det spurt et noe ledende spørsmål.

"Litt unødvendig fag, men det må vel til"

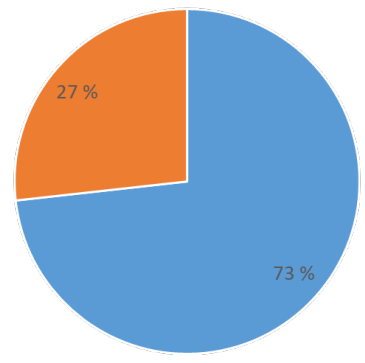

且 "Enig" 且 "Uenig"
"Litt unødvendig fag, men det må vel til"

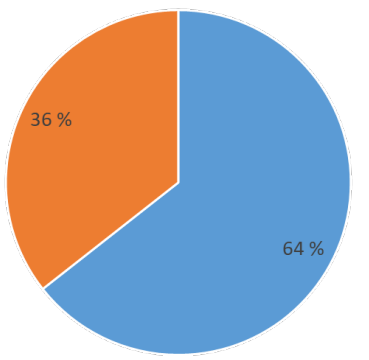

플 "Enig" 38 回"Uenig" 21

Fig. 6. Studentenes vurdering av emnet. a) førsteårsstudenter b) avgangsstudenter

Cirka tre fjerdedeler av studentene syntes emnet var «Litt unødvendig emne, men det må vel til». Avgangsstudentene var noe mer positive til emnet enn førsteårsstudentene. I samtaler med studenter uttrykte de ofte at de så på emnet som påtrykt fra undervisningsmyndighetene, og at det hadde lite relevans for dem.

\subsubsection{Struktur}

I en del tilbakemeldinger fra underveisevalueringene var det uttrykt et savn av en rød tråd i emnet. Det ble derfor spurt om det var flere studenter som opplevde det slik.
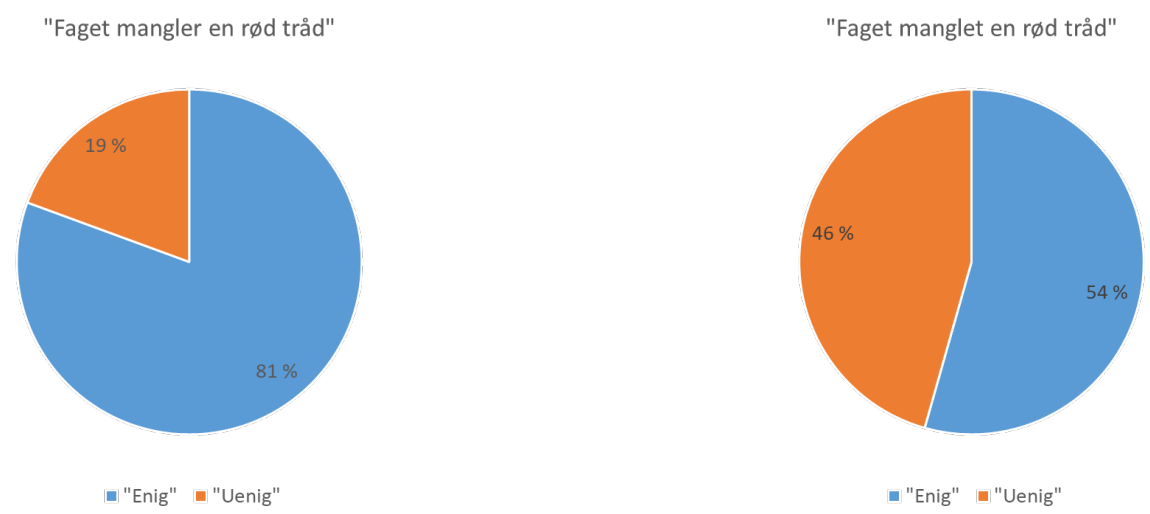

Fig. 7. Studentenes vurdering av manglende rød tråd. a) førsteårsstudenter b) avgangsstudenter

Spesielt førsteårsstudentene savnet den røde tråden, mens avgansgstudentene ikke opplevde det i like stor grad. Utfordringen er at emnet inneholder mange ulike tema og undervisere. Dette er nok en undervisningsform som studentene ikke er vant med fra tidligere, og som krever mer modenhet av dem som studenter. Det ser ut til å være enklere å se strukturen i emnet etter at det er fullført enn underveis i undervisningen. 


\subsubsection{Plassering i studiet}

Det var også interessant å spørre studentene om når i studieforløpet emnet «Innføring i ingeniørfaglig yrkesutøvelse og arbeidsmetoder» passet best.

Her var både førsteårsstudenter og avgangsstudenter enige om at det passet bra å ha emnet tidlig i studiet. Avgangsstudentene som hadde mulighetene til å se dette i perspektiv av et helt studieløp, var veldig klare på at det var fornuftig å ha det tidlig.

Hadde dette faget egnet seg bedre senere i studiet?

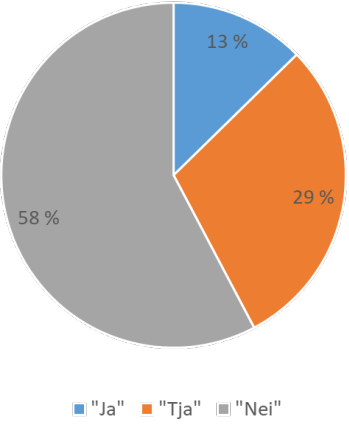

Fig. 8. Emnets plassering.
Hadde dette faget egnet seg bedre senere i studiet?

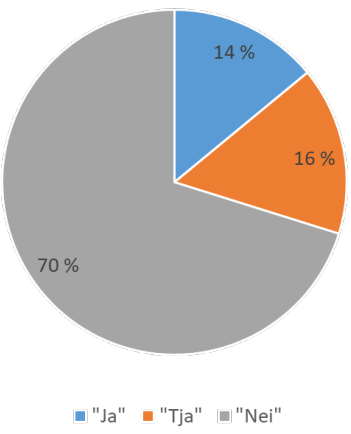

b) avgangsstudenter

\subsubsection{Helhetsinntrykk}

Brorparten av studentene vi spurte synes at emnet var greit nok, og andelen som synes det var fullstendig irrelevant er vesentlig mindre enn i 2012. Det ser også ut til at førsteårsstudentene er litt mindre kritiske til emnet enn avgangsstudentene; Kun ti prosent ser det som fullstendig irrelevant, og dette kan tyde på at emnet har utviklet seg positivt gjennom årene. Lærerne har gjort noen justeringer underveis som kan ha gjort studentene mer positive til emnet, men det kan også tenkes at studentenes erfaring gjennom studiet har påvirket synet på emnet, og at det virker mindre relevant sammenlignet med studiet for øvrig.

Hvordan er helhetsinntrykket ditt av faget?

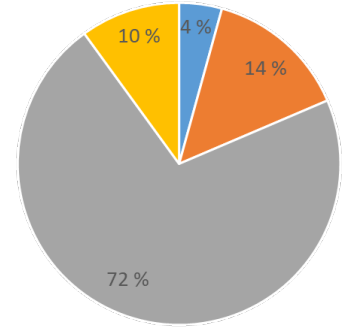

- "Nyttig og interessant" - " "Nyttig og variert"

- "Greit nok" = "Kjedelig og irrelevant"
Hvordan var helhetsinntrykket ditt av faget?

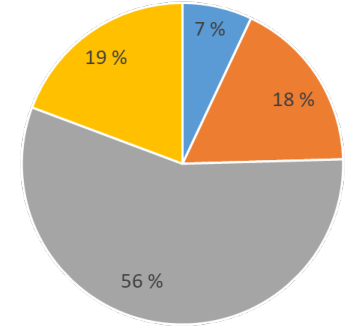

프 "Nyttig og interessant" ๒ ๒ "Nyttig og variert"

느 "Greit nok" 는 "Kjedelig og irrelevant"

Fig. 9. Helhetsinntrykket av emnet. a) forsteårsstudenter b) avgangsstudenter

\subsubsection{Korrelasjoner mellom ulike surveysporsmål}

\section{Førsteårsstudenter:}

Blant dem som syntes emnet var greit nok, er det en større spredning i hvilke deler av emnet som ble vurdert som interessant. Blant dem som syntes emnet var kjedelig og irrelevant, er det hele $83 \%$ som mente at prosjekt var det mest relevante, og 33\% som mente det burde vært mer om prosjekt i emnet. For de øvrige er det $61 \%$ som mente prosjekt var det mest relevante, og 33\% som ønsket mer prosjekt.

\section{Avgangsstudenter:}

Blant dem som syntes emnet var greit nok, er det en større spredning i hvilke deler av emnet som ble vurdert som interessant. Blant dem som syntes emnet var kjedelig og irrelevant, er det $64 \%$ som mente 
at prosjekt var det mest relevante, og 73\% som mente det burde vært mer om prosjekt i emnet. For de øvrige er det bare $36 \%$ som mente prosjekt var det mest relevante, og 52\% som ønsket mer prosjekt.

Det ser ut som om avgangsstudenter ikke anser prosjekt som det viktigste i like høy grad som førsteårsstudentene. En forsiktig tolkning av denne korrelasjonen mellom emnet relevans og ønsket om prosjekt, er at det finnes to 'typer' studenter. De som primært er på jakt etter 'her og nå' nytteverdi som prosjekt gir, og en studentgruppe som også er åpen for de andre temaene som tas opp. Denne tolkningen understøttes også av studentenes evaluering av emnet «Innføring i ingeniørfaglig yrkesutøvelse og arbeidsmetoder».

Utover dette er det ingen signifikante korrelasjoner mellom de ulike spørsmålene som ble stilt i surveyen.

\subsection{Evalueringer}

«Innføring i ingeniørfaglig yrkesutøvelse og arbeidsmetoder» har blitt undervist fire ganger siden høsten 2012. Et utvalg av studentenes generelle kommentarer til den teoretiske delen av emnet fra underveisevaluering i 2012 og 2016 er gjengitt med kommentarer. Som en vil se, er studentene mer fornøyd med undervisningen i 2016 enn i 2012. Det ser altså ut som om de pedagogiske grep som lærerne tok fungerer. Det er fremdeles en del studenter som ikke ser hensikten med emnet i 2016, men det er vesentlig færre enn ved oppstart i 2012.

I 2012 var emnet nyutviklet, lærerne syntes de hadde laget et godt opplegg på tross av den korte tiden til forberedelse. Det var med en viss forventning de så frem til å få høre studentenes mening om faget i underveisevalueringen. Det skal ikke legges skjul på at lærerne ble sjokkert. Der en trodde man skulle få ros ble en møtt med massiv, totalt $20 \mathrm{~A} 4$ sider, kritikk. Et studentutsagn som på en måte oppsummerte den gjennomgående kritikken var «Jeg synes det som blir gjennomgått har vært veldig svada så langt.».

At studentene kunne mene at elektrohistorie, vitenskapsteori og etikk var svada, kom som en overraskelse på lærerne. Avstanden mellom det vi trodde studentene kunne være opptatt av og hva de egentlig syntes var formidabel. Det ble også pekt på at en del at informasjonen som ble gitt i og for seg var interessant, men ikke relevant «Det blir mye snakk om ingenting til tider. Mye av informasjonen er interessant, men ikke relevant». De likte måten det ble fremført på, men nytteverdien manglet. «Dumt er et dårlig ord. Jeg syns det er vanskelig å se noe relevans i det som Per underviser i. Han er veldig dyktig og jeg synes det er artig å høre på han».

En del studenter påpekte at de hadde erfaring fra næringslivet, og at emnet derfor var meningsløst. «Meiningsløst fag for studentar med relevant erfaring frå arbeidslivet». Dette til tross for at emnet tok opp etiske problemstillinger basert på eksempler fra næringslivet.

Noen studenter syntes det var et tøysete emne som stjal av deres dyrebare tid. «Tullete fag som tar opp tid og som vi ikkje lærer noko av». «Personlig så syntes jeg det er et tøyse fag». «Slutte å tulle!!!». Ingen prøvde å forklare hva som var så tøysete.

Det ble laget en kronikkoppgave som lærerne mente var fornuftig for at studentene skulle få trening med sjangeren, og skulle kunne delta i den offentlige debatten. Tilbakemeldingenen var klare «Mye tid kastes bort på stilskriving som alle jeg har snakket med føles totalt ubrukelig og irrelevant». Selv etter å blitt forklart hva en kronikk er og hvordan den skal skrives, var det et flertall av studentene som leverte det en kan kalle en skolestil. Mange av studentene mente at ingeniøren ikke hadde noe behov for å kunne delta i det offentlige ordskiftet. Det gjenspeiler kanskje det faktum at det er få ingeniører som deltar i samfunnsdebatten.

Ved å bruke «Blade Runner» (Scott, 1982) en filosofisk science fiction film med dystopiske trekk og den mer optimistiske boken «Physics of the future» av Michio Kaku (Kaku, 2011), ønsket lærerne også å få studentene interessert i fremtiden og hvilke muligheter som lå der. At vi ikke helt traff publikum kunne tilbakemeldinger som «Finn emner som kanskje ikke bare er relevante, men og INTERESSANTE! Starte faget med en film om fremtiden? Supert! Men gode gud, velg en film der mer 
enn $1 / 10$ av studentene klarer å holde seg våkne! 'Klassiker' fra 1986 som viser hvordan de så på fremtiden på den tid-" IRRELEVANT!» og «Mye uinteressant informasjon. F.eks kildebruk, sci-fi filmer, sci-fi bøker. Ble anbefalt at vi skulle lese sci-fi bøker. Jeg ser rett og slett ikke vitsen med det og har heller ikke tid til å lese bøker utenom studiene» tyde på.

Med de negative tilbakemeldingene som kom i store mengder med underveisevalueringen, ville det enkleste være å gi opp, og heller lage et innhold tilpasset studentenes ønsker. At andre kanskje hadde valgt den løsningen, kunne undersøkelsen «Didaktiske refleksjoner om ingeniørfaglig innføringsemne» til Schive tyde på (Schive, 2015). Vi valgte å beholde temaene i vårt emne ING104 og heller se på den pedagogiske og faglige tilnærmingen. Basert på en sluttevaluering og egne erfaringer ble undervisningsopplegget bedre tilpasset publikum. Kreative elementer som bruk av film og tilleggslitteratur ble fjernet, mer studentaktive læringsformer ble innført, og tvillingforelesninger ble innført for å få opp temperaturen i møtet med studentene.

Underveisevalueringer $\mathrm{i}$ årene som fulgte ble generelt mer positive, og mengden negative tilbakemeldinger avtok. Når en sammenligner underveisevalueringen fra 2016 med den fra 2012, så er det generelle inntrykket mye bedre. Studentene er mer tilfredse, uten at man har måttet kompromisse med emnets faglige innhold. Det er den pedagosiske vinklingen som har gjort mottakelsen bedre.

Når vi ser på enkeltkommentarer fra studenter i underveisevalueringen i 2016, så er det fremdeles noen som ikke helt ser hva de skal med emnet og kommer med utsagn som «Litt unødvendig fag, men det må vel til» og «I innføringsemnet vet jeg ikke hva vi skal lære. Tror det handler om væremåte, oppførsel, arbeidsmoral og etikk som ingeniør».

Bruken av responssystemer ble godt tatt i mot. «Kahoot gir veldig bra læringsutbytte. Det er engasjerende og jeg følger med på en annen måte, enn når det kun foreleses. Det gjør at jeg får med meg hva som er riktig og hva som ikke er riktig til senere anledninger». Lærerne trodde at responssystemer ville være en 'dille' som fort ville gå av moten, men det er fascinerende å se hvilket engasjement enkle spørsmål genererer hos studentene i forelesningssalen. Responssystemene brukes nå til surveyer av nye studenter for å lære dem å kjenne bedre som gruppe, og i undervisningen som avbrekk og repetisjon.

Tvillingforelesningene har gitt en helt ny dynamikk i forelesningene. Studentene deltar selv om det er hundre i salen, og oppkonstruert uenighet mellom foreleserne øker engasjementet. Studentenes respons til undervisningsformen er hyggelig lesning for oss lærere - «Veldig bra undervisning», «Jeg liker hvordan de klarer å holde presentasjonene på en måte som får faget til å bli mer gøy enn det er. Det gir både motivasjon og trivsel i timene», «Artig og gøy! Men kunne være bedre informasjon!», «Det er vanskelig å putte fingeren på noe. Lærerne har vært svært trygge og rolige som har gitt en fin flyt på det de har gått igjennom» og «Gode forelesere, men det er også ett fag som ikke har så veldig mye å snakke om i mine øyne». De fleste forelesningene avsluttes med klapping fra studentene, men det er jo nærmest teater det som foregår så det passer bra.

Da emnet inneholder mange faglige elementer er det en del studenter som savner den røde tråden «Vanskelig å se den røde tråden i faget, noe som kan føre med seg en viss umotiverende holdning» og «Vanskelig å se hva faget om handler i sin helhet, manglende rød tråd». Vi prøver å fortelle studentene ved oppstart hva som skal gjennomgås i hvilken rekkefølge og hvorfor, men vi har forståelse for at studentene synes at emner favner vidt selv om vi bare har foretatt et nennsomt utvalg av de viktigste temaene som rammeplanens nasjonale retningslinjer (Universitets- og høgskolerådet, 2011) foreslår.

En del studenter savner det konkrete og er bekymret for hvordan eksamen vil se ut - «Veldig gode forelesere, men vil gjerne høre litt mer om hvordan eksamen foregår og hva eksamen går ut på i dette faget». Emnet har nå blitt undervist i fem år, og vi bruker tid på slutten til å gjennomgå eksamensoppaver. Vi oppfordrer også studentene tidlig i semesteret til å se på eksamensoppgaver for å se hva de kommer til å bli målt på. 


\section{DISKUSJON}

C.P. Snow påpekte den manglende interesse for naturvitenskap blant humanister (Snow, 2008). Våre undersøkelser blant ingeniørstudenter, viser at de heller ikke er synderlig interessert utover snevre faggrenser. Motviljen mot ex. phil. lignende emner er stor blant ingeniørstudenter (Svendsen, 2016). En mulig forklaring er at våre studenter i hovedsak har ingeniører som foreldre og undervises av ingeniører i sin utdannelse.

I likhet med funnene hos Alpay et al. (Alpay, Ahearn, Graham, \& Bull, 2008) er våre studenter mest interessert i de praktiske oppgavene og har den samme motvilje mot akademisering som Alpay et al. fant.

Våre funn står i sterk kontrast til Alpay et al. sine målinger, og Bolognaprosessen og rammeplanenens intensjoner når det gjelder interessen for de såkalte store spørsmål. Våre studenter viste liten interesse for disse temaene, og den pedagogiske og faglige tilnærming måtte endres for i det hele tatt å nå frem til studentene med budskapet.

Dersom en på sikt ønsker å øke ingeniørers interesse for dannelsesspørsmål, er det viktig at også deres stemme blir hørt når dannelse diskuteres. Det er ikke tilfelle nå hvor en har hatt dannelsesutvalg uten en eneste teknolog som medlem (Dannelsesutvalget for høyere utdanning, 2009).

For fremtidig arbeid vil det være av interesse å finne ut mer om hvorfor den praktiske delen av «Innføring i ingeniørfaglig yrkesutøvelse og arbeidsmetoder» er så mye mer populær enn den teoretiske delen. Skyldes det aversjon mot teori, eller ser studentene den praktiske delene som mer nyttig i forhold til fremtidig yrkeskarriere?

\section{KONKLUSJON}

Det er et ønske å innføre Ex. phil. i alle høyere utdanninger (Arbeiderpartiet, 2016), (Waaler, 2016) og (Svendsen, 2016). Våre erfaringer med å undervise i «Innføring i ingeniørfaglig yrkesutøvelse og arbeidsmetoder» tilsier at en må tilpasse emnets innhold og undervisningsmetoder til ulike studentgrupper for å lykkes. Hos en del ingeniørstudenter er nyttetenkningen så sterk at de frarøver seg selv muligheten til å utvide egen horisont og se seg selv i et større perspektiv. Hva så med C.P. Snows (Snow, 2008) ønske om å forene de to kulturer? For å få det til må ingeniørene ta dannelse på alvor, men det kreves holdningsendringer i humaniora også. Lærerutdanningen ved vår egen institusjon HVL har «Ein utdana mann og eit dana menneske» av Jon Hellesnes (Hellesnes, 1969) som pensum. Der kan en lese «Fagmannen ser hårstrittande, ufjelga og distré opp frå sine partiklar og strukturar. Han ser seg rundt og forstår ingenting». Denne avvisningen av dem som skaper verdier, viser at man fremdeles har et stykke vei å gå for kulturell fellesforståelse.

\section{TAKK}

Forfatterne takker våre studenter og kolleger, Høgskulen på Vestlandet, og Kunnskapsdepartementet.

\section{REFERANSER}

Alpay, E., Ahearn, A. L., Graham, R. H., \& Bull, A. M. (2008). Student enthusiasm for engineering: charting changes in student aspirations and motivation. European Journal of Engineering Education, 33, ss. 573-585.

Andersen, E. S., \& Schwencke, E. (2012). Prosjektarbeid - en veiledning for studenter. NKI-forlaget. doi:ISBN13: 9788256272303

Arbeiderpartiet. (2016, November). Med kunnskap skal landet bygges videre. Hentet fra https://khrono.no/sites/default/files/ap-strategi_for_hoyere_utdanning_og_forskning_2016nett.pdf

Arup, O. (2017, 11). AZ Quotes. Hentet fra AZ Quotes: http://www.azquotes.com/quote/1378440

Dannelsesutvalget for høyere utdanning. (2009). Kunnskap og dannelse foran et nytt århundre. 
European Federation of National Engineering Associations. (2017, 11). The EUR ING Title. Hentet fra FEANI: www.feani.org

Grøttvik, O. (2012, oktober 19). Idealistiske ingeniører. Bergens Tidende.

Heitmann, G. (2005). Challenges of engineering education and curriculum development in the context of the Bologna process. European Journal of Engineering Education, 30, ss. 447-458.

Hellesnes, J. (1969). Ein utdana mann og eit dana menneske - Framlegg til eit utvida daningsbegrep. Bergen: Filosofisk institutt, Universitetet i Bergen.

Hjelle, J. (2012, oktober 30). Her bråvåkner studentene. Bergens Tidende.

Kahoot. (2017). Kahoot. Hentet fra https://kahoot.com/

Kaku, M. (2011). Physics of the future. Doubleday. doi:ISBN: 9780307473332

Kjelsberg, R. (2017). Teknologi og vitenskap. Universitetsforlaget. doi:ISBN: 9788215024806

Lovdata. (2011). Forskrift om rammeplan for ingeniørutdanning. 2011. Oslo. Hentet fra https://lovdata.no/dokument/SF/forskrift/2011-02-03-107

Lönngren, J. (2014). Engineering Students' Ways of Relating to Wicked Sustainability Problems. Gothenburg: Chalmer University of Technology.

Myklebust, S. (2013, desember 12). Brygging som del av undervisningen. Hentet fra Ølportalen: http://olportalen.no/2013/12/12/brygging-som-del-av-undervisningen/

NOKUT. (2008). Evaluering av ingeniørutdanningen $i$ Norge 2008. Oslo: NOKUT. Hentet fra http://www.nokut.no/Documents/NOKUT/Artikkelbibliotek/Norsk_utdanning/Evaluering/IN GEVA/Rapporter/INGEVA_NOKUT_\%20del\%201\%20Hovedrapport.pdf

Ormestad, H., \& Øgrim, O. (u.d.). Fysikk på roteloftet. NRK TV.

Raaheim, A. (2013). Råd og tips til deg som underviser. Gyldendal, Norsk forlag. doi:ISBN 9788205443532

Rørvik, T. I. (1999). Historien om examen philosophicum 1675 - 1983. Oslo: Forum for universitetshistorie. doi:NO-OsNB (990010121264702202)

Schwanitz, D. (2005). Dannelse. Pax. doi:ISBN: 9788253027708

Scott, R. (Regissør). (1982). Bladerunner [Film].

Snow, C. (2008). De to kulturer. Bokklubbens kulturbibliotek. doi:ISBN: 9788252568448

Store norske leksikon. (2017). Dannelse. Hentet fra https://snl.no/dannelse

Svendsen, O. M. (2016, November). Ex.phil - et uroelement. Hentet fra https://khrono.no/debatt/exphil-et-uroelement

Søk \& skriv. (2017). Søk \& skriv. Hentet fra Søk \& skriv: sokogskriv.no

Thorvaldsen, P., \& Henne, I. (2014). Propagation measurements on a line-of-sight over-water radio link in Norway. AGU Publications, Wiley. doi:10.1002/2013RS005338

Universitets- og høgskolerådet. (2011). Nasjonale retningslinjer for ingeniørutdanningen. Hentet fra http://www.uhr.no/documents/Retningslinjene_med_ny_versjon_av_kapitell_9_og_vedlegg_ 6 _desember_2014_L_39590_.pdf

Waaler, N. (2016, Desember). Forberedt på framtiden. Hentet fra https://khrono.no/debatt/forberedt-pafremtiden 